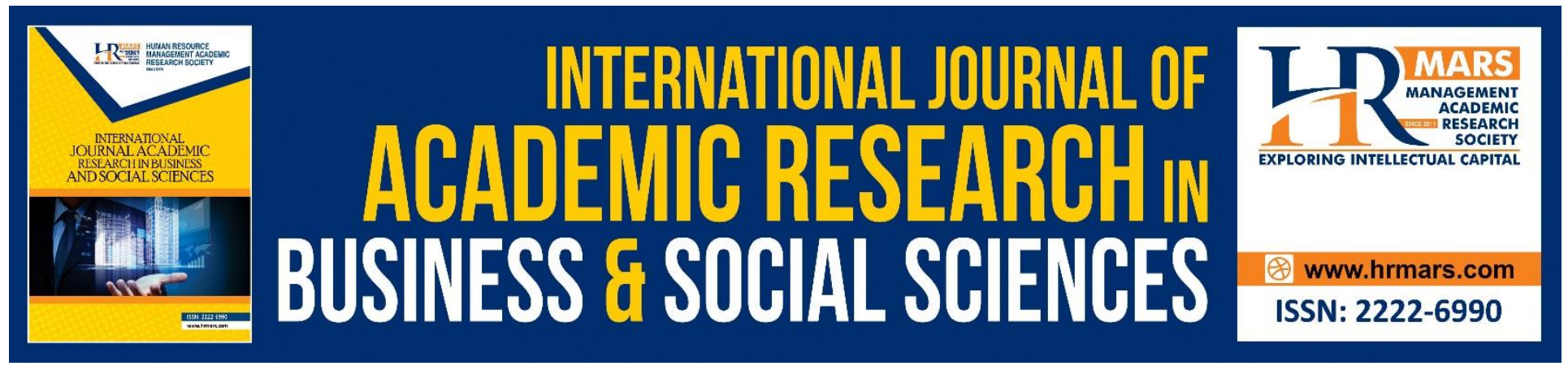

\title{
Perception, Awareness, and Practice of Environmental Management - The Case of Small Batik Enterprises in Kelantan, Malaysia
}

Kamaruddin Mardhiah, Mohd Rafi Yaacob, Mohamad Nizamuddin Bin Abdul Rahim \& Nur Faizah Mat Zain

To Link this Article: http://dx.doi.org/10.6007/IJARBSS/v8-i9/4864

DOI: $\quad 10.6007 /$ IJARBSS/v8-i9/4864

Received: 06 August 2018, Revised: 27 August 2018, Accepted: 29 Sept 2018

Published Online: 15 October 2018

In-Text Citation: (Mardhiah, Yaacob, Rahim, \& Zain, 2018)

To Cite this Article: Mardhiah, K., Yaacob, M. R., Rahim, M. N. B. A., \& Zain, N. F. M. (2018). Perception, Awareness, and Practice of Environmental Management - The Case of Small Batik Enterprises in Kelantan, Malaysia. International Journal of Academic Research in Business and Social Sciences, 8(9), 1532-1540.

Copyright: (C) 2018 The Author(s)

Published by Human Resource Management Academic Research Society (www.hrmars.com)

This article is published under the Creative Commons Attribution (CC BY 4.0) license. Anyone may reproduce, distribute, translate and create derivative works of this article (for both commercial and non-commercial purposes), subject to full attribution to the original publication and authors. The full terms of this license may be seen

at: http://creativecommons.org/licences/by/4.0/legalcode

Vol. 8, No. 9, September 2018, Pg. 1532 - 1540

http://hrmars.com/index.php/pages/detail/IJARBSS

JOURNAL HOMEPAGE

Full Terms \& Conditions of access and use can be found at http://hrmars.com/index.php/pages/detail/publication-ethics 


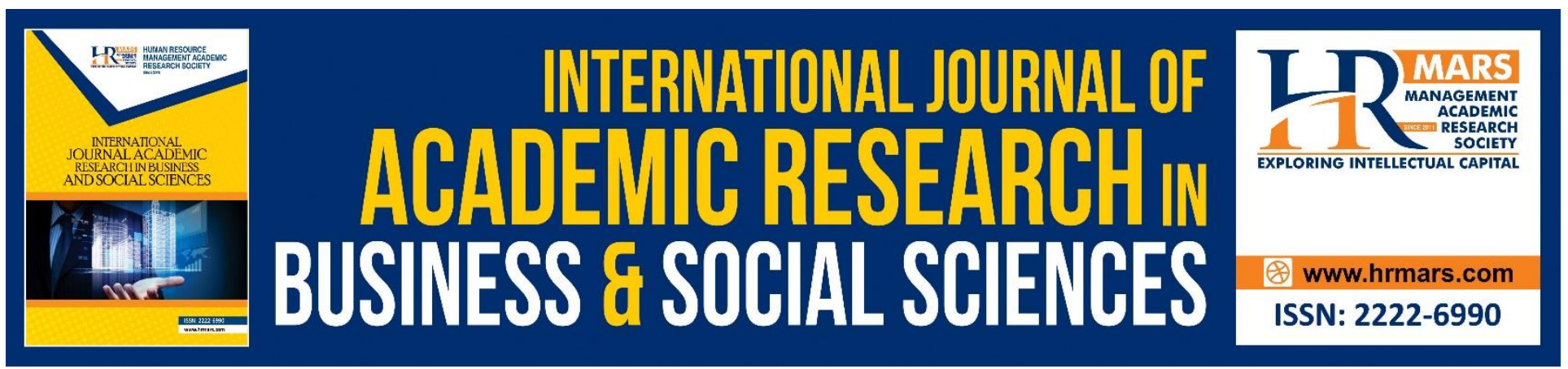

\title{
Perception, Awareness, and Practice of Environmental Management - The Case of Small Batik Enterprises in Kelantan, Malaysia
}

\author{
Kamaruddin Mardhiah, Mohd Rafi Yaacob, Mohamad Nizamuddin \\ Bin Abdul Rahim \& Nur Faizah Mat Zain \\ Faculty Entrepreneurship and Business, Universiti Malaysia Kelantan, Malaysia
}

\begin{abstract}
Batik industry is one of handiwork products in Malaysia that has contributed significantly to the country economy particularly to the state of Kelantan and Terengganu. The majority of Batik enterprises is categorized as small business. But nevertheless, the majority of the public and not a few owners do not realize that the industry has negative environmental impacts, mainly water pollution. In Malaysia research pertaining to the environmental performance of the industry is lacking as academicians are more focus to study business activities which have direct relationships with financial performance. Although environmental issues are more and more important to businesses over the past three decades, in Malaysia they are not given priority as businesses perceived them as secondary. This paper identifies the entrepreneurs' perception, awareness, and practice of environmental issues among Batik entrepreneurs in Kelantan. A cross-sectional study was done from 1st April-31st May 2015. A simple random sampling was applied and a questionnaire was distributed to the owner-managers from thirty-six batik premises in Kelantan. It is shown that the premises still had a lower mean score of perception, awareness, and practice towards environmental management. The finding of this research can help to increase awareness of Batik entrepreneurs on environmental issues because it is important to practice environmentally friendly in the industry.
\end{abstract}

Keywords: Perception, Awareness, Practice, Environmental Management, Environmental Performance, Batik Entrepreneurs

\section{Introduction}

Industrial growth influence on social life and the environment. It is important for humans to sustain a friendly business environment. One of the issues that arise and triggers the need to pay more attention to the environment is global warming. Alertness of environmental problems activated the industry to supply products that promote the concept of environmental matters or better known as the green. Consumers of the product aware and accept the concept of growing green as their new 
lifestyle. Design for environmental or green design is an action that is carried out by considering the environmental impacts produced by the product life cycle, in order to improve the competitive level, adding market value added, lower costs or preservation of environmental. (Ulrich, 2001).

The two main objectives of environmental design are to prevent waste and to optimize the use of materials (Hundal, 2000). It was reported that the rapid development of green industries will optimize energy and material consumption (DeMendoca, 2001). A green product is a product that has a good quality which is capable to care the healthiness of the environment and to reserve resources. An effective product is a product that is able to provide benefits in accordance with perceived by consumers (Ulrich, 2001). Therefore, it is essential to consider the quality of the products based on the needs and desires of consumers by starting to produce environmentally friendly products. Most industries have a negative impact in the form of industrial surplus. Type of waste caused comes from the production or non-production process. The production process produce the wastewater and the rest of the production produce the solid waste. The size of the charge depend on the management of environmental.

Over the last four decades, more and more businesses have embraced environmental management as a response to mixed results of escalating stakeholders' pressures that warrant sustainable business activities. Prior to the 1980s, environmental management was considered as 'alien' in the business lexicon. Due to increased awareness of environmentalism amongst the public that has exerted considerable pressure on businesses which partly responsible for environmental degradation, businesses could not help but internalize and embrace environmental matters in their business considerations. In many cases, the public does not exert direct pressure on business but voice their dissatisfaction to related government agencies and in turn, regulate new laws or execute existing laws.

Environmental management which considered as the externality, now steadily and increasingly has been given duly consideration. Not only businesses include environmental aspects in their strategies but at the same time shape their businesses activities and allocate a significant amount of money of environmental matters. However, albeit much talks and debates of what is called the sustainable business or green business (Cekanavicius, et al., 2014) in practice, only small numbers of businesses have embraced this very concept or idea. As a result of their sheer sizes that are easily exposed to the public big organizations including Multinational Corporations have embraced sustainability to show they are environmentally conscious. The same is also observed for environmentally damaging businesses, due to stakeholder's pressure especially regulatory pressure, they have been enforced to buy sustainable business concept and abide with environmental laws and regulations. So it does not come as a surprise, academicians pay considerable attentions towards these two categories of business, leaving academic lacunae of environmental management in small and medium-sized businesses.

Batik industry in Kelantan is considered as small medium enterprises (SMEs) or also known as cottage industry which referred to small scale industry (Subki et al., 2011). Unfortunately, it was 
INTERNATIONAL JOURNAL OF ACADEMIC RESEARCH IN BUSINESS AND SOCIAL SCIENCES Vol. 8, No. 9, Sept. 2018, E-ISSN: 2222-6990 @ 2018 HRMARS

reported that batik industry in Kelantan has only five per cent level of compliance with the department's law and regulations between January and September 2010 when compared to other industrial industry (Subki et al., 2011).

Generally, most research concerning to small business enterprises (SMEs) and environmental performance were conducted in developed countries (Welford, 1993, Shaper, 2002, Tilley, 1999a, 1999b, Debby, 2008; Groundwork, 1995; Friedman \&Miles, 2001; and Hillary, 2004). A number of related studies were also conducted in developing countries (Sonnenfeld, 2000; Frijns, Phuong and Arthur 2000; Rao, 2000). However, only a few researchers have delved into this particular research area in Malaysia (Yaacob, Mahmood \& Nik Ismail, 2007, Yaacob, 2010, Mat Zain \& Yaacob, 2014). In order to close the gap in the body of knowledge pertaining to green business, this research is timely and indeed pertinent. The aim of this study is to describe the level of perception, awareness, and practice among Batik entrepreneurs in Kelantan.

\section{Methodology}

List of 120 batik entrepreneurs provided by the Malaysian Handicraft Development Corporation (Batik) of Kelantan in 2014 was used as the sampling frame. Data were collected from the 1st April - 31st May 2015 which involved 36 (30\%) of the total population of batik premises in

Kelantan.

This study employed the method of primary data collection using a 5 Likert scale questionnaire as the research instrument. The questionnaire was used to collect the information based on variables perception, awareness, and practice. Environmental awareness was measured based on the knowledge of the environmental impact of business activities, benefits of business environmental initiatives, environmental policy, clarity regarding environmental performance, environmental legislation, cost benefits and production efficiency improvement. Environmental perception had 5 items that dealt with knowledge the consciousness to link business and environment, business and environment relation, future business friendly prospect, environmental conservation and environmental regulation. Environmental practices contained 30 items in three categories pertaining to the premise housekeeping, raw material usage, water usage, electricity usage, good and comfortable workspace, waste management and employees' health and safety. One of the researchers personally visited batik premises after making appointments on phone according to entrepreneur's availability and some by walk-in. The reasons why the researcher preferred face to face meeting due to: (i) the respondents from rural villagers, (ii) most of them do not have a higher education leads to difficult to understand academic language.

Descriptive analysis was performed to identify the mean (SD) of perception, awareness, and practice. Meanwhile, 3-axis plot was used to illustrate the level of this three variables. IBM SPSS Statistics Data Editor (Version 24.0) used to perform data entry and data analyses.

\section{Research Findings}

Table 1 shows demographic profiles of small batik enterprises for the study. A total of 36 batik enterprises from several locations in the state of Kelantan participated in this study. As far as ages of 
INTERNATIONAL JOURNAL OF ACADEMIC RESEARCH IN BUSINESS AND SOCIAL SCIENCES Vol. 8, No. 9, Sept. 2018, E-ISSN: 2222-6990 @ 2018 HRMARS

respondents were concerned, majority of entrepreneurs were between 40 to 50 years old (47.2\%), followed by less 40 years (27.8\%). Only $16 \%$ more than 50 years old. $94.4 \%$ of them were from secondary level of education and another $5.6 \%$ were from tertiary level of education. More than $58.3 \%$ of batik enterprises in the survey established more than 10 years. The rest, $25 \%$ of them were established between 6 to 9 years, and 16.7\% equal to less than 5 years. Half of the enterprises employed between 6 to 10 permanent staff, followed by $36.1 \%$ of them hired 5 and below permanent staff, and another $13.9 \%$ employed more than 10 permanent staff. Judging from this figure, $16.7 \%$ of the samples came from micro business and $83.3 \%$ were under small business. As far as part-time staff were concerned overwhelming batik enterprises (52.8\%) less than RM10, 000 . Only $2.8 \%$ start-up capital more than RM20, 000 leaving the rests (43.2\%) between these two figures. Descriptive analysis of each domain are shown in Table 2 indicates the mean (SD) of awareness, and practice are $2.78(0.71)$, and $3.05(0.63)$ respectively. The median (IQR) for perception was 4.00 (1.60). As shown in Figure 1, only one premise showed a higher level of the score of perception, awareness, and practice.

Table 1. The Demographic Profile of Entrepreneurs

\begin{tabular}{|l|c|}
\hline \multicolumn{1}{|c|}{ VARIABLES } & $\mathrm{n}(\%)$ \\
\hline Age & \\
$<40$ & $10(27.8)$ \\
$40-50$ & $17(47.2)$ \\
$<50$ & $9(16.0)$ \\
\hline Level of education & \\
Secondary & $34(94.4)$ \\
Tertiary & $2(5.6)$ \\
\hline Years of enterprise & \\
5 and below & $6(16.7)$ \\
6 to 10 & $9(25.0)$ \\
$>10$ & $21(58.3)$ \\
\hline Employee full time & \\
5 and below & $13(36.1)$ \\
$6-10$ & $18(50.0)$ \\
$>10$ & $5(13.9)$ \\
\hline Employee part time & \\
5 and below & $35(97.2)$ \\
$>5$ & $1(2.8)$ \\
\hline Start-up capital (RM) & \\
10,000 and less & $19(52.8)$ \\
$10,001-20,000$ & $16(43.2)$ \\
$>20,000$ & $1(2.8)$ \\
\hline
\end{tabular}


INTERNATIONAL JOURNAL OF ACADEMIC RESEARCH IN BUSINESS AND SOCIAL SCIENCES Vol. 8, No. 9, Sept. 2018, E-ISSN: 2222-6990 @ 2018 HRMARS

Table 2. Descriptive Analysis of Perception, Awareness, and Practice

\begin{tabular}{|c|c|}
\hline DOMAIN & MEAN(SD) \\
\hline Perception & $4.00(1.60)^{\mathrm{a}}$ \\
\hline Awareness & $2.78(0.71)$ \\
\hline Practice & $3.05(0.63)$ \\
\hline${ }^{a}$ median(IQR) \\
\hline
\end{tabular}

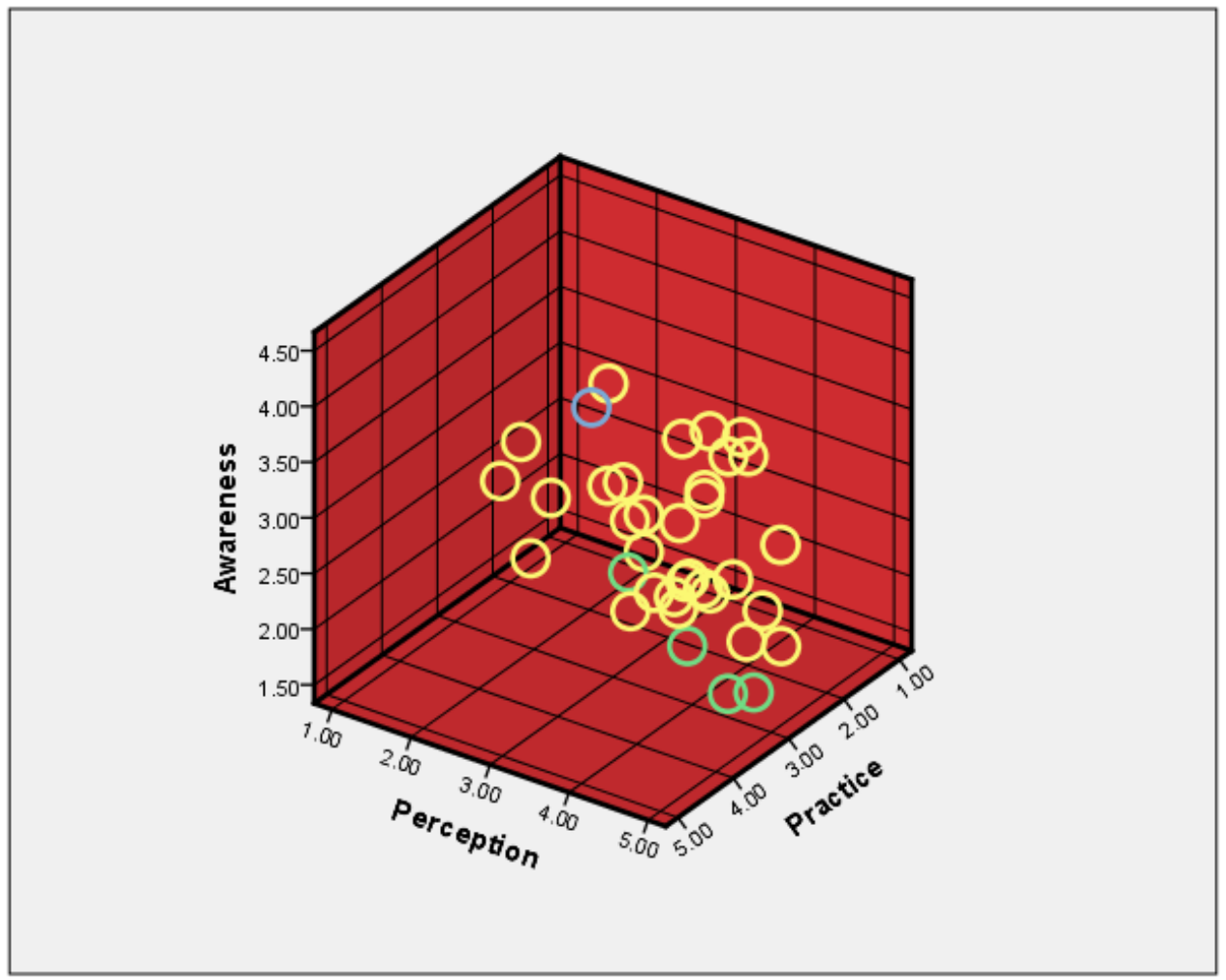

Figure 2. 3-axis plot of perception, awareness, and practice

\section{Discussion and Conclusion}

Based on the study, the level of environmental awareness and practice among batik entrepreneurs in Kelantan was still low and not widely embraced them. Most of them were not exposed to the environmental issues such as soil contamination, water and air pollution in batik industry. Meanwhile, only a few of them have good adoption in implementing green business and the majority do not have good ventilation in their premises. However, they had an average score of environmental perception. But when discussing to the overall level of environmental perception, awareness, and practice among batik entrepreneurs in Kelantan, it still can be considered as low. Only one premise exhibited the higher level of mean perception, awareness, and practice which is more than 4.0. As reported in 2011, batik premises in Kelantan documented the lowest percentage of environmental compliance (62.50\%) while other industrial industries like metal fabrication, electric 
and electronic, food and drink, leather, batik handicraft, rubber based, and textile recorded $100 \%$ compliance (Malaysian Department of Environment, 2011). The common issue that appears related to the Batik industry is water pollution as this industry utilizes a lot of chemicals from the wastewater (McClatchy, 2011). It contains grease, heavy metal, wax, dyes and suspended solid (McClatchy, 2011).

Batik industries create a huge involvement in Malaysia's economy growth. Nevertheless, batik industries also produce large amounts of wastes with a high concentration of poisons which required comprehensive action before discharging into the environment (Subki et al., 2011). In order to change the mindsets of Batik entrepreneurs as well as to address the problem about this issue, an intervention study should be conducted by exposing them to the negative sides of the industry to the surrounding and its required long and hard way to push them to the next level. It is crucial for both the top administration team and employees to understand the important of practicing a good environmental management when environmental performance improvement is achieved.

The main challenges for them to be environmentally practice were time, knowledge and lack of experts in this area. The majority of the premises in Kelantan did not perform when it came to environmental management due to lack of awareness and knowledge. It is important to develop a proper instrument to expose the entrepreneurs with the knowledge on environmental management in Batik industry.

In addition, Batik entrepreneurs should consider to enhance and implement a new method of managing a good environmental management in their industry and at the same time quantifying the performance of the environmental. In European countries, $40 \%$ of SMEs show environmental responsibility and $32 \%$ of them that have not yet followed this trend are anticipating doing so in the future (Rabadan et al., 2017). The role of top management in being sensitive to environmental issues is important to sustain their business. Towards sustainable development, firms and industries have begun to manage environmental aspects of their business for sustainability. Measuring ecological performance of the industry is a good decision to overcome the pollution problem in Malaysia. It shows that the cooperation from the industrial sector is also vital to implement the plans and strategies to reduce the pollution.

As a conclusion, entrepreneurs should make a proactive effort to sustain their venture in this industry and to make sure they make some practice towards this issue and it's essential to develop an awareness and positive perception in environmental management among Batik entrepreneurs. Textile industry wastes and variation in the wastewater presents multi-components pollutants that are difficult to be preserved adequately (Yean et al., 2012). In order to achieve the preferred water quality, biological treatment such as pre or post treatment should had be done.

\section{Corresponding Author}

Mardhiah binti Kamaruddin, Faculty of Entrepreneurship and Business, Universiti Malaysia Kelantan, Malaysia, Email: mardhiah.k@umk.edu.my 
INTERNATIONAL JOURNAL OF ACADEMIC RESEARCH IN BUSINESS AND SOCIAL SCIENCES

Vol. 8, No. 9, Sept. 2018, E-ISSN: 2222-6990 @ 2018 HRMARS

\section{References}

Jimenez, J.B. \& Lorente, J.J. (2001). An analysis of Environmental Management, Organisational Context \& Performance of Spanish Hotels. Omega, 29(6), 457-471.

Debby F.M. (2008). Environmental Behaviour in Chicago Automotive Repair Micro-enterprises (MEPs). Business Strategy and the Environment, 17, 194-207.

Biondi, V., Iraldo, F.,\& Merediths, S. (2002). Achieving Sustainability Through Environmental Innovation: The Role of SMEs. International Journal of Technology Management, 24(5-6), 612625.

Cekanavicius, L., Bazyte, R. \& Dicmonaite. A. (2014). Green Business: Challenges and Practices. Ekonomika, 9(1), 74-88.

Dandridge, T.C. (1979). Children are not and Little Grown Up: Small Business Needs its Own Organisational Theory. Journal of Small Business Management, 17, 53-57.

DeMendonça, M., and Baxter, T.E. (2001). “Design for the environment (DFE): An Approach to achieve the ISO 14000 international standardization", Environmental Management and Health, Vol. 12 No. 1, pp. 51-56.

Department of Environment Kelantan Annual Report 2011.

Groundwork (1995). Small Firms and the Environment. Birmingham, Groundwork Foundation.

Hundal, M. S., 2000. Life Cycle Assessment and Design for the Environment. International Design Conference - Design, Dubrovnik, May 23 - 26, 2000. Zagreb, FMENA, 2000, pp 171-174.

Mat Zain, F. \& Yaacob. M.R (2014). Green Model in Batik Industry - A Strategy for Sustainability in Craft Industry in Malaysia. Chapter 30 in Corporate Social Responsibility: Business \& Societal Perspective. Edited by Saurabh Mittal \& Emmy Indrayani. Published by SERD, New Delhi, India. pp.248-255.

McClatchy (2011). Switch to 'green' batik. Tribune Business News, 6 October 2011.

Rao, P.H. (2000). Environmental Management Systems in Southeast Asia: Towards a Green Millennium. Asian Institute of Management.

Schaper, M. (2002). Small firms and environmental management: Predictors of green purchasing in Western Australian pharmacies. International Small Business Journal 20(3): 235-249.

Sonnenfeld, D.A. (2000). Contradictions of Ecological Modernisation: Pulp and Paper Manufacturing in South East Asia. Environmental Politics, 9(1): 235-256.

Subki, Noor \& Hashim, Rohasliney \& Zuhartini Md Muslim, Noor. (2014). Heavy Metals Analysis of Batik Industry Wastewater, Plant and Soil Samples: A Comparison Study of FAAS and HACH Colorimeter Analytical Capabilities. 285-289. 10.1007/978-981-4560-70-2_52.

Tilley, F. (1999a). Small-Firm Environmental Strategy, Green Management International, 25, 67-80.

Tilley, F. (1999b). The Gap Between the Environmental Attitudes and the Environmental Behaviour of Small Firms. Business Strategy and the Environment, 8(4):238.

Ulrich, K. T., and S. D. Eppinger, (2001). Perancangan dan Pengembangan Produk, Salemba Teknika, Jakarta.

Welford, R. \& Gouldson, A. (1993). Environmental Management and Business Strategy. London. Pitman.

Welsh, J.A. and White, J.F. (1981). A Small Business is not a Big Business, Harvard Business Review, 59(4), 18-32. 
INTERNATIONAL JOURNAL OF ACADEMIC RESEARCH IN BUSINESS AND SOCIAL SCIENCES

Vol. 8, No. 9, Sept. 2018, E-ISSN: 2222-6990 @ 2018 HRMARS

Yaacob, M. R. \& Nik Ismail, N.R. (2007) Perniagaan Kitar Semula -Kajian Awal Pengusaha PKS di Kelantan. Paper presented at the Persidangan Kebangsaan Industri Kecil \& Sederhana, Kota Kinabalu Sabah, Malaysia, December 4-5.

Yaacob (2010). Small enterprises environmental management practices in Terengganu, Malaysia. Gyan Management, Vol.4(1), pp. 2-14.

Yean, L. P., Ahmad Z. A. (2012). Current status of textile industry wastewater management and research progress in Malaysia: a review. Clean-Soil, Air, Water, 2013. 